\title{
A 2007-08 Social Accounting Matrix for Pakistan
}

\section{Dario Debowicz, Paul Dorosh, Sherman Robinson and Syed Hamza Haider}

This paper presents the latest Social Accounting Matrix of Pakistan (SAM) for the year 2007-08. Our proposed approach to estimating SAMs is motivated by an information theoretic approach to estimation (Judge \& Mittelhammer, 2012) that takes a Bayesian perspective on the efficient use of information: "Use all the information you have, but do not assume any information you do not have." The methodology used to develop this SAM ensures that it is perfectly consistent with the National Accounts. The SAM includes 51 sectors of activity, 27 factors of production, and 18 household groups, allowing tracing direct and indirect effects of potential scenarios through production and consumption linkages and capture distributional effects. We illustrate the use of the SAM using a semi input-output multiplier model. Output multipliers in Pakistan, accounting for supply constraints, range between 1.1 and 1.4, and shocks to livestock and industry have the largest spillover effects. 


\section{PAKISTAN Strategy Support Program}

\section{INTRODUCTION}

A Social Accounting Matrix (SAM) is a single-entry internally consistent accounting system that documents all the economic transactions within an economy. It supports the continuing need to use recent and consistent multisectoral economic data for policy analysis and the development of economy-wide models (Robinson, Cattaneo, \& El-Said, 2001). It is an extended set of national accounts that disaggregates value-added in each production activity into payments to various factors such as land, labor, and capital, and disaggregates household incomes and expenditures according to various household types. Mathematically, a SAM is a square matrix in which each account is represented by a row and a column. Each cell shows the payment from the account of its column to the account of its row. Thus, the incomes of an account appear along its row and its expenditures along its column. The underlying principle of double-entry accounting requires that, for each account in the SAM, total revenue (row total) equals total expenditure (column total).

A limited number of Social Accounting Matrixes have been constructed for Pakistan in the past (Table 1.1). The first countrywide social accounting matrix (SAM) for Pakistan dates to 1979 and was built by the Pakistan Institute of Development Economics (PIDE) in 1985. This was followed by a SAM for the year 1984-85, created by the Federal Bureau of Statistics (FBS), with collaboration with the Dutch government under the Improvement of National Accounting System (INAS) project. Since this SAM had a single household group, it was not suited for analyzing distributional effects across households.

Siddiqui and Iqbal (1999) generated a new SAM for 1989-90 and disaggregated data with eight household groups. It aggregated the Input-Output (IO) table industry classifications into five production accounts, namely agriculture, industry, health, education and other sectors. In 2004, Dorosh, Niazi, and Nazli (2004) produced a SAM of Pakistan for the year 2001-02. It contained 19 household groups and 34 production accounts. Since the households were disaggregated by province and the number of commodities were larger than Siddiqui and lqbal (1999), it was more suitable for analyzing effects of shocks in specific industries on different socioeconomic groups. Later, Waheed and Ezaki (2008) created a financial SAM for the year 1999-2000. While the previous SAMs were mainly built on the real economy, growing importance of capital flows and availability of associated data allowed the authors to disaggregate the workings of the loanable funds market into disaggregated payments related to physical and financial flows among institutions. ${ }^{1}$ Production activities were aggregated into six accounts: i) agriculture, ii) mining and quarrying, iii) manufacturing, iv) electricity, water, and gas, v) construction, and vi) other sectors.

We build a SAM for Pakistan for financial year 2007-08 that relies on contemporaneous National Accounts and household data, as well as information present in the SAM built by Dorosh, Niazi, and Nazli (2004) ${ }^{2}$. This work is part of the Pakistan Strategy Support Program, which supports the Government of Pakistan with evidence-based policy reform for propoor economic growth and enhanced food security. The SAM has started and is expected to be used with Computable General Equilibrium (CGE) modeling to analyze the macro and distributional impact of policy changes throughout the economy. ${ }^{3}$

Compared to the disaggregation in Dorosh, Niazi, and Nazli (2004), the textile industry has been further disaggregated into knitwear, garments, and other textiles. The cotton lint-yarn activity has been disaggregated between ginning, spinning, and weaving. Chemicals account has also been disaggregated as fertilizers and other chemicals. As in most developing

\footnotetext{
${ }^{1}$ Typically captured with a single saving $^{\text {-investment account. }}$

2 July 1, 2007 -June 30, 2008.

${ }^{3}$ The full SAM is available from the authors upon request.
} 
countries, Pakistan's services sector has been growing in importance so its disaggregation is crucial for policy relevant analysis. Reflecting this, trade has been divided between wholesale, retail, and other trade, while the transport sector now has separate accounts for road, rail, air, water, and other transport. Housing has been divided between rented and owned, while private sector service is disaggregated into education, health care, business services, personal services, and other private services.

We have explicitly included four types of economic agents in our SAM, namely producers, households, government, and the rest of the world. Households are disaggregated according to province and agricultural households are further divided by farm ownership and size. ${ }^{4}$ Non-agriculture households are divided by whether they are urban or rural and by expenditure quintiles (1, 2, and others). Out of the 18 household groups, 12 represent agricultural households. This enables an in depth analysis of the agricultural sector and its linkages with other industries.

The paper is organized in the following way. Section 2 explains how the SAM was generated. Section 3 briefly analyzes the structure of the Pakistan economy in light of the SAM. Section 4 demonstrates the use of the SAM with income multiplier analysis and Section 5 concludes.

Table 1.1-Previous SAMs for Pakistan

\begin{tabular}{|c|c|c|}
\hline Nr. & Name of researchers/organization & Salient Features \\
\hline 1 & $\begin{array}{l}\text { Pakistan Institute of Development Economics } \\
\text { (1985) }\end{array}$ & Base year: 1979 \\
\hline 2 & Federal Bureau of Statistics $(1993)^{5}$ & Base year: 1984-85 \\
\hline 3 & Siddiqui and Iqbal (1999) & $\begin{array}{l}\text { Base year: } 1989-90 \\
\text { Sectors (5): agriculture, industry, education, health, other sectors } \\
\text { Agents: households (8), firms, government, rest of the world }\end{array}$ \\
\hline 4 & Dorosh, Niazi, and Nazli (2004) & $\begin{array}{l}\text { Base year: 2001-02 } \\
\text { Sectors (34): agriculture (12), industry (16), services (6) } \\
\text { Agents: households (19), enterprises, government, rest of the } \\
\text { world }\end{array}$ \\
\hline 5 & Waheed and Ezaki (2008) & $\begin{array}{l}\text { Base year: } 1999-00 \\
\text { Sectors(6): agriculture, mining and quarrying, manufacturing, } \\
\text { electricity, water and gas, construction, other sectors } \\
\text { Agents: households, firms, government, commercial banks, } \\
\text { central bank, rest of the world }\end{array}$ \\
\hline
\end{tabular}

\section{METHODOLOGY FOR GENERATING SAM}

Our proposed approach to estimating SAMs is motivated by an information theoretic approach to estimation (Judge \& Mittelhammer, 2012) that takes a Bayesian perspective on the efficient use of information: "Use all the information you have, but do not assume any information you do not have." Previous work on SAM estimation using this approach includes: Judge and Mittelhammer (2012), Golan, Judge et al. (1994), Robinson, Cattaneo et al. (2001), Golan, Judge et al. (1996), Debowicz (2010), and Zellner (2004).

To generate the SAM following this approach, we followed a series of major steps that are explained in Figure 2.1. The steps, which are explained in detail below, start from a schematic SAM (Table 2.1) and, using a variety of data sources, and balancing the accounts of the SAM with the use of a 'cross-entropy' technique, lead to a macro-consistent and disaggregated SAM.

Table 2.2 shows the numerical macro-SAM that we arrived at, and Table 2.3 shows the data sources that we utilized to go from the schematic macro-SAM to the numerical one.

\footnotetext{
${ }^{4}$ Medium/Large farm households are defined as those owning farms with 12.5 acres or more land. Small farm households are those owning less than 12.5 acres of land.

${ }^{5}$ We did not find it possible to get access to these SAMs.
} 
Figure 2. I-Steps to build the SAM for Pakistan 2007-08

Start with the scherratic SAvilfigure 2.2)

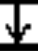

Various dete sources (iisted in igure 23) are used to generate aggegated SAM(igure 2.4) using

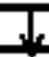

Generate Proto-SAM 1Abydisggegating sectors. The procedure is described in this section

$\sqrt{1}$

Generate Proto-SAM 1 B byconducting sector-specic adjustmerts on supply or dertand to reduce imbalances

$\sqrt{1}$

Generate balanced Proto-SAM 1Cusing cross-ertropy sotw are, cortrolling for values in aggregated SAMt

\section{1}

Generate Proto-SAM 2Aby disaggregating factors and households. The procedure is described in this section

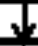

Geneste Proto-SAlw2B byconducting sector-specic adjustmerts on supply or derrand to reduce imbalances

$\sqrt{2}$

Generate disaggegated and balanced SAMMusing crossentropy sotw are, cortrolling tor values in aggregated SAM 
Table 2.I-A Schematic Social Accounting Matrix (SAM) for Pakistan

\begin{tabular}{|c|c|c|c|c|c|c|c|c|c|c|}
\hline & Activities & Commodities & Land & Labor & Capital & Households & Government & $\begin{array}{l}\text { Change } \\
\text { in stocks }\end{array}$ & $\begin{array}{c}\text { Saving- } \\
\text { Investment }\end{array}$ & $\begin{array}{l}\text { Rest of the } \\
\text { World }\end{array}$ \\
\hline Activities & & Supply matrix & & & & & & & & \\
\hline Commodities & $\begin{array}{l}\text { Intermediate } \\
\text { consumption }\end{array}$ & & & & & $\begin{array}{l}\text { Final private } \\
\text { consumption }\end{array}$ & $\begin{array}{l}\text { Final public } \\
\text { consumption }\end{array}$ & $\begin{array}{l}\text { Change } \\
\text { in stocks }\end{array}$ & $\begin{array}{l}\text { Fixed } \\
\text { investment }\end{array}$ & Exports \\
\hline Land & $\begin{array}{l}\text { Value added } \\
\text { by land }\end{array}$ & & & & & & & & & \\
\hline Labor & $\begin{array}{l}\text { Value added } \\
\text { by labor }\end{array}$ & & & & & & & & & \\
\hline Capital & $\begin{array}{l}\text { Value added } \\
\text { by capital }\end{array}$ & & & & & & & & & \\
\hline Households & & & $\begin{array}{l}\text { Payment } \\
\text { from land to } \\
\text { households }\end{array}$ & $\begin{array}{l}\text { Payment } \\
\text { from labor to } \\
\text { households }\end{array}$ & $\begin{array}{l}\text { Payment } \\
\text { from capital } \\
\text { to house- } \\
\text { holds }\end{array}$ & & $\begin{array}{l}\text { Transfers from } \\
\text { government to } \\
\text { households }\end{array}$ & & & $\begin{array}{l}\text { Remittance } \\
\text { to house- } \\
\text { holds }\end{array}$ \\
\hline Government & & $\begin{array}{l}\text { Sales and } \\
\text { imports tax }\end{array}$ & & & $\begin{array}{l}\text { Payment } \\
\text { from capital } \\
\text { to public } \\
\text { sector }\end{array}$ & Direct taxes & & & & $\begin{array}{l}\text { Transfers } \\
\text { from non- } \\
\text { residents to } \\
\text { government }\end{array}$ \\
\hline $\begin{array}{l}\text { Change in } \\
\text { stocks }\end{array}$ & & & & & & & & & $\begin{array}{l}\text { Change in } \\
\text { stocks }\end{array}$ & \\
\hline $\begin{array}{l}\text { Saving- } \\
\text { Investment }\end{array}$ & & & & & & $\begin{array}{l}\text { Household } \\
\text { saving }\end{array}$ & $\begin{array}{l}\text { Government } \\
\text { saving }\end{array}$ & & & $\begin{array}{l}\text { Foreign } \\
\text { saving }\end{array}$ \\
\hline $\begin{array}{l}\text { Rest of the } \\
\text { World }\end{array}$ & & Imports & & & $\begin{array}{l}\text { Repatriation } \\
\text { of dividends } \\
\text { and utilities }\end{array}$ & & $\begin{array}{l}\text { Government } \\
\text { payments to } \\
\text { RoW }\end{array}$ & & & \\
\hline
\end{tabular}


Table 2.2 - Macro-SAM for Pakistan (in Billions of Pakistani Rupees)

\begin{tabular}{|c|c|c|c|c|c|c|c|c|c|c|c|c|c|c|}
\hline & $\begin{array}{c}\text { Activi- } \\
\text { ties }\end{array}$ & $\begin{array}{c}\text { Com- } \\
\text { modities }\end{array}$ & Land & Labor & Capital & $\begin{array}{l}\text { House- } \\
\text { holds }\end{array}$ & $\begin{array}{c}\text { Gov- } \\
\text { ernment }\end{array}$ & $\begin{array}{c}\text { Sales } \\
\text { Tax }\end{array}$ & $\begin{array}{c}\text { Import } \\
\text { Tax }\end{array}$ & $\begin{array}{c}\text { Direct } \\
\text { Tax }\end{array}$ & Stocks & $\begin{array}{l}\text { Saving- } \\
\text { Invest- } \\
\text { ment }\end{array}$ & $\begin{array}{c}\text { Rest of } \\
\text { the } \\
\text { World }\end{array}$ & Total \\
\hline Activities & & 25,743 & & & & & & & & & & & & 25,743 \\
\hline Commodities & 15,822 & & & & & 8,046 & 1,278 & & & & 164 & 2,095 & 1,502 & 28,907 \\
\hline Land & 576 & & & & & & & & & & & & & 576 \\
\hline Labor & 2,651 & & & & & & & & & & & & & 2,651 \\
\hline Households & & & 576 & 2,651 & 5,998 & & 617 & & & & & & 763 & 10,605 \\
\hline Government & & & & & 442 & & & 171 & 151 & 391 & & & 27 & 1,181 \\
\hline Sales Tax & & 171 & & & & & & & & & & & & 171 \\
\hline Import Tax & & 151 & & & & & & & & & & & & 151 \\
\hline Direct Tax & & & & & & 391 & & & & & & & & 391 \\
\hline Stocks & & & & & & & & & & & & 164 & & 164 \\
\hline $\begin{array}{l}\text { Saving- } \\
\text { Investment }\end{array}$ & & & & & & 2,168 & -777 & & & & & & 868 & 2,259 \\
\hline $\begin{array}{l}\text { Rest of the } \\
\text { World }\end{array}$ & & 2,842 & & & 254 & & 63 & & & & & & & 3,160 \\
\hline Total & 25,743 & 28,907 & 576 & 2,651 & 6,695 & 10,605 & 1,181 & 171 & 151 & 391 & 164 & 2,259 & 3,160 & \\
\hline
\end{tabular}


Table 2.3-Sources of data for Macro -SAM

\begin{tabular}{|c|c|}
\hline Macro-SAM Item & Source \\
\hline Value added by land & $\begin{array}{l}\text { National Accounts, Gross National Product at Current Factor Cost } 2007-08 \text { of agricul- } \\
\text { tural sectors (FBS) multiplied by share of land in value added of agricultural sectors } \\
\text { from Dorosh et al. (2004) }\end{array}$ \\
\hline Value added by labor & $\begin{array}{l}\text { National Accounts, Gross National Product at Current Factor Cost } 2007-08 \text { for each } \\
\text { sector (FBS) multiplied by share of labor into value added of the sector in Input-Output } \\
\text { matrix (1991) (IO91). }\end{array}$ \\
\hline Value added by capital & $\begin{array}{l}\text { National Accounts, Gross National Product at Current Factor Cost 2007-08 minus two } \\
\text { above. }\end{array}$ \\
\hline Intermediate consumption & $\begin{array}{l}\text { National Accounts, Gross National Product at Current Factor Cost } 2007-08 \text { for each } \\
\text { sector multiplied by ratio between intermediate consumption and value added in those } \\
\text { activities in Input-Output matrix (1991). }{ }^{6}\end{array}$ \\
\hline Supply matrix & Sum of payments above \\
\hline Direct tax & "Fiscal Development" item "Direct Taxes" 2007-08, Economic Survey (2009) \\
\hline Import tax & $\begin{array}{l}\text { "Pakistan: Summary of consolidated federal and provincial revenue 2007-08" Taxes on } \\
\text { International Trade, Economic Survey (2009) }\end{array}$ \\
\hline Sales tax & Handbook of Statistics (2010), Table 1.4, Indirect taxes - Subsidies - Import Tax \\
\hline Final public consumption & $\begin{array}{l}\text { Handbook of Statistics (2010), Table 1.4, General Government Consumption Expendi- } \\
\text { ture FY08 }\end{array}$ \\
\hline Change in stocks & Handbook of Statistics (2010), Table 1.4, Changes in Stocks FY08 \\
\hline Fixed Investment & Handbook of Statistics, Table 1.4, Gross Domestic Fixed Capital Formation FY08 \\
\hline Exports & $\begin{array}{l}\text { IMF Country Report (2010), Table 3.1, Pakistan: Balance of Payments, 2007-08. } \\
\text { "Exports: FOB" + "Services: Credit" }\end{array}$ \\
\hline Imports & $\begin{array}{l}\text { IMF Country Report (2010), Table 3.1, Pakistan: Balance of Payments, 2007-08. } \\
\text { "Imports: FOB" + "Services: Debit" }\end{array}$ \\
\hline Final private consumption & Residual of commodity account \\
\hline $\begin{array}{l}\text { Payment from land to } \\
\text { households }\end{array}$ & Value added by land \\
\hline $\begin{array}{l}\text { Payment from labor to } \\
\text { households }\end{array}$ & Value added by labor \\
\hline $\begin{array}{l}\text { Repatriation of dividends and } \\
\text { utilities }\end{array}$ & $\begin{array}{l}\text { IMF Country Report (2010), Table 3.1, Pakistan: Balance of Payments 2007-08. } \\
\text { "Income: debit" + "Current Transfers: debit" - "Income: credit" }\end{array}$ \\
\hline $\begin{array}{l}\text { Payment from capital to public } \\
\text { sector }\end{array}$ & Handbook of Statistics (2010), Table 3.7, Residual of Public Incomes \\
\hline Government saving & $\begin{array}{l}\text { Pakistan: Summary of Consolidated Federal and Provincial Budgetary Operations, } \\
\text { Provisional. Table 1.1, Budget Deficit 2007-08, Economic Survey (2009) }\end{array}$ \\
\hline $\begin{array}{l}\text { Government payments to non- } \\
\text { residents }\end{array}$ & $\begin{array}{l}\text { IMF Country Report (2010), Table 3a, Share of Foreign into Total Payment of Interest } \\
\text { by GOP 2008-09 (not available for 2007-08) multiplied by Handbook of Statistics } \\
\text { (2010), Table 3.7, Interest Payment FY08 Consolidated Federal and Provincial } \\
\text { Governments }\end{array}$ \\
\hline $\begin{array}{l}\text { Transfer from non-resident to } \\
\text { government }\end{array}$ & $\begin{array}{l}\text { Handbook of Statistics (2010), Table 7.2, Net Current Transfers of General Government } \\
\text { in Balance of Payments FY08 }\end{array}$ \\
\hline $\begin{array}{l}\text { Transfer from government to } \\
\text { household }\end{array}$ & Residual in government account \\
\hline
\end{tabular}

\section{I. Generation of the First Proto-SAM (PSAM IA)}

The next step was to split domestic value added into 51 sectors of activity in the SAM (listed in Box 2.1, together with the rest of the SAM accounts). For this purpose, we started from value added by major sector, as in 2007-2008 Gross National Product at current factor cost in National Accounts, which sums to the value added in the Macro-SAM. To split the major sectors present in this classification into those present in the SAM, as illustrated in Figure 2.2, we conducted the following steps:

- Major and minor crops were disaggregated into wheat, rice, cotton, sugarcane, fruits and vegetables, and other field crops using the 2007-08 data from Agricultural Statistics of Pakistan (2009), "Gross value addition of Major Crops at Current Factor Cost" and "Gross value addition of Minor Crops at Current Factor Cost".

- Rice and wheat were further split using production of rice varieties and irrigated and non-irrigated wheat from Agriculture Statistics of Pakistan.

\footnotetext{
${ }^{6}$ The classification of activities in 1091 is presented in Appendix 1.
} 
- Livestock was split into poultry and other livestock using the value of their output as informed also by the Agriculture Statistics of Pakistan.

- Manufacturing was split into vegetable oil, wheat milling, rice irri-milling, rice basmati-milling, refinement of sugar, other food, lint, yarn, cloth, knitwear, garments, other textiles, leather, wood, fertilizer, other chemicals, cement, petroleum refining, and other manufacturing using the most recent available Census of Manufacturing and Industry (CMI) (2006).

- Trade was split into wholesale, retail, and other using the "Study on wholesale and retail trade, hotels and restaurants in Pakistan," Federal Bureau of Statistics (2002).

- Transport was split into road, rail, water, air, and other such as transport by tubes, using "National Accounts of Pakistan: Rebasing from 1980-81 to 1999-2000", Federal Bureau of Statistics (2004).

- Housing was split into owned and non-owned using the "Survey on Community and Personal Services," Federal Bureau of Statistics (2001).

- "Social, community, and personal" services was split into business, education, health, personal, and other services using the same source.

Once the value added of each sector in the SAM was estimated, we split the values into payments to land, capital, and labor. For the crops in the SAM, this was done using the factor shares at activity level in the cost of production of Pakistan (2003) informed by the Agriculture Policy Institute (formerly known as Agricultural Prices Commission). Wheat factor shares were updated using cost of production data for 2008-09 from the Agriculture Policy Institute (2009). For the remaining activities, the shares of labor and capital were informed by Dorosh, Niazi, and Nazli (2004), IO91, and the map from sectors in 10 to those in SAM (Appendix 2).

Then, we split the intermediate use using the production cost of Pakistan 2002-03 for crops and the IO91 for rest. The supply of each activity was allocated to its corresponding commodity, generating the sector-specific supply matrix. Import taxes were generated by multiplying value imported of each commodity 2007-08, available from Ministry of Commerce (2011) by its tariff rate, available from Federal Board of Revenue (2008). 7 Sales tax is split proportional to production value of each commodity. The sector composition of imports and exports were informed mainly by 2007-08 trade data in the Pakistan Economic Survey (2009), and supplemented by 2008 import data from the Government of Pakistan Ministry of Commerce and United Nations Conference on Trade and Development (2008). The sector composition of private final consumption is informed by expenditures present in the Household Income and Expenditure Survey of Pakistan (2008), expanding with sample household weights, and translating into the commodities in the SAM, as detailed in Appendix 3. The sector composition of fixed investment, changes in stocks, and public final consumption was informed by IO91 and the respective mapping into SAM accounts.

\footnotetext{
${ }^{7}$ Given data availability, we ignore secondary production.
} 
Box 2.I-Accounts in the SAM

\begin{abstract}
Activities (51)
Agriculture (12): Wheat irrigated, Wheat non-irrigated, Rice-Irri (irrigated), Rice-Basmati (irrigated), Cotton (irrigated), Sugarcane (irrigated), Other field crops, Fruits/vegetables, Livestock (cattle, milk), Livestock (poultry), Forestry, Fishing Industry (22): Mining, Vegetable oils, Wheat milling, Rice milling (irri), Rice milling (basmati), Sugar, Other food, Cotton gin (lint), Cotton spin (yarn), Cotton weave (cloth), Knitwear, Garments, Other textiles, Leather, Wood, Chemicals, Fertilizers, Cement and bricks, Petroleum refining, Other manufacturing, Energy, Construction

Services (17): Trade-wholesale, Trade-retail, Trade-other, Transport-rail, Transport-road, Transport-water, Transport-air, Transport-other, Housing, Imputed rent, Business services, Health care, Education, Personal services, Other private services, Public services, Finance and insurance
\end{abstract}

\title{
Commodities (50)
}

Same as activities except Wheat irrigated and Wheat non-irrigated activities aggregated as one commodity (Wheat).

\section{Factors (27)}

Labor (10): Own-farm (Large farm, Medium farm Sindh, Medium farm Punjab, Medium farm Other Pakistan, Small farm Sindh, Small farm Punjab, Small farm Other Pakistan), Agricultural waged, Non-agricultural unskilled, Non-agricultural skilled

Land (12): Large farm (Sindh, Punjab, Other Pakistan), Irrigated medium farm (Sindh, Punjab, Other Pakistan), Irrigated small farm (Sindh, Punjab, Other Pakistan), Non-irrigated small farm (Sindh, Punjab, Other Pakistan)

Otherfactors (5): Water, Capital livestock, Capital other-agriculture, Capital formal, Capital informal

\section{Households (18)}

Rural (15): Large/medium farm (Sindh, Punjab, Other Pakistan), Small farm (Sindh, Punjab, Other Pakistan), Landless unwaged farmer (Sindh, Punjab, Other Pakistan), Landless waged farmer (Sindh, Punjab, Other Pakistan), Rural non-farm per capita expenditure quintile 1 , quintile 2 , and rest Urban (3): per capita expenditure quintile 1, quintile 2, and rest

Other Institutional Accounts (4)

Government (including separate subaccounts for import taxes, direct taxes, and sales taxes), Rest of world, Saving-Investment, Change in stocks 
Figure 2.2-Split of value added among sectors in the SAM

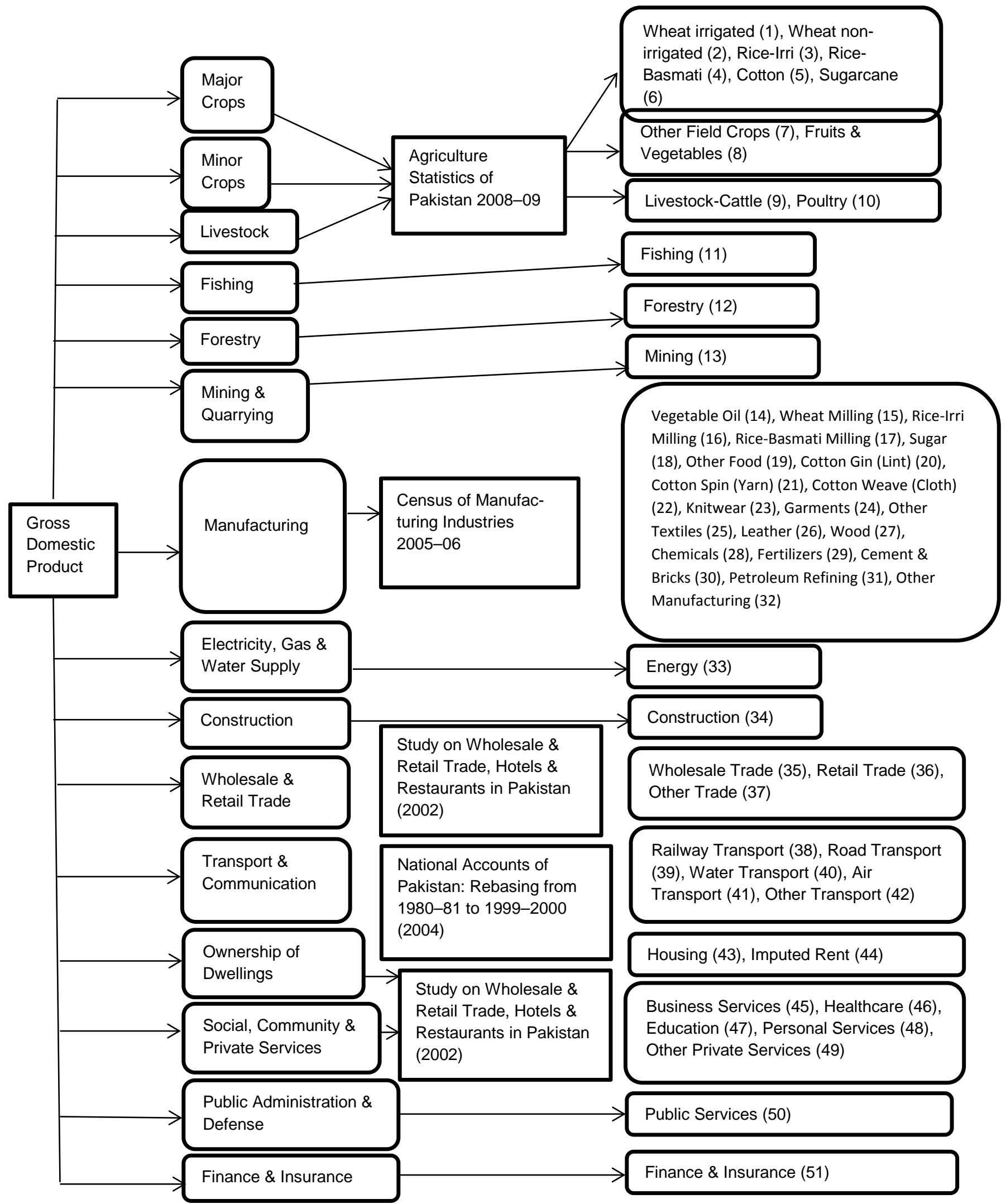




\subsection{Balancing the First Proto-SAM to Get to PSAM-IC}

After a series of adjustments that reduced the imbalances at the commodity level to be less than $30 \%$ of the average between supply and use, we arrived at a new proto-SAM (PSAM 1B). We then generated a consistent proto-SAM based on it, seeking to minimize the cross-entropy distance between the proto-SAM and the SAM imposing the series of controls present in the Macro-SAM (PSAM 1C). When balancing the SAM at this stage, and following the approach described in Golan, Judge, and Robinson (1994), we treated every cell in the SAM as being specified with an error support set whose weights are estimated to minimize a cross-entropy distance between the prior and the solution SAM. This treatment is strongly related to the one described in Robinson, Cattaneo, and El-Said (2001), with key differences. In the previous approach, the column coefficients in the SAM were treated analogously to probabilities and included directly in the crossentropy minimand, generating the need for special treatment of negative cells and accounts with zero sums in the SAM. In the approach we apply, developed by Sherman Robinson and Scott McDonald - starting in turn from Robinson, Cattaneo, and El-Said (2001) -, the cross-entropy minimand only includes probability weights for a selected error support set, such that the SAM coefficients are no longer treated as analogous to probabilities and negative entries and accounts with zero sums do not require any special treatment. 8 The present approach allows specification of a prior estimate of the mean and standard error of selected cell entries (expressed either as values or column coefficients), column sums, and macro aggregates. These errors can be specified as additive or multiplicative-exponential. For the aggregates present in the Pakistan Macro-SAM, we set a zero standard error. This allowed us to arrive at a SAM that is perfectly consistent with the MacroSAM, such that the sum of the value added in the solution SAM was exactly equal to the GDP at factor cost in the MacroSAM; the private final consumption in the solution SAM summed exactly the private final consumption in the Macro-SAM, etc.

\subsection{Disaggregating the Payments Related to Factors and Households}

To fully disaggregate the single household group and the three factors (labor, capital, and land) present in PSAM 1C into the complete set of 27 factors and 18 households in the SAM, we conducted the following steps. The value added of the specific activities was split among the 27 factors using the shares present in the 2000-2001 SAM for Pakistan, in turn informed by the PRHS (Pakistan Rural Household Survey 2001). Then, regarding payments from factors to institutions, after assigning the payments from factor income to government and non-residents as informed by the Macro-SAM to formal capital, the household income matrix was generated in the following way (Figure 2.3).

Labor, agricultural capital, and non-agricultural formal capital were split following the Household Income and Expenditure Survey (HIES) 2007-08 incomes. Livestock was split following the value of the livestock capital stock owned by households in HIES 2007-08. Land and water income was split following the 2000-01 SAM, which in turn is based on the PRHS. For land, all returns to land of large farms (defined in terms of cultivated area) are paid to large landowners in proportion of farm area of respective regions. For medium and small farms in each region, returns to land are allocated to the four types of farmers (large, medium, small, and landless) according to the shares of each group in total land revenues of small and medium farms, derived from data from the PRHS 2001-02. Specifically, returns of small and medium-sized farms for each region (Punjab, Sindh, and Other Pakistan) were allocated to households according to the following formula: LandShareh = (CultAreah - rr * Land_Inh + rr * Land_Outh) / Total Cultivated Area, where LandShareh is the share of household $\mathrm{h}$ in total land revenues, CultAreah is cultivated area of household h, $\mathrm{rr}$ is the rental cost of land (assumed to be 50\%), Land_Inh is net land rented in of household $\mathrm{h}$, and Land_Outh is net land rented out of household $\mathrm{h}$.

Returns to informal non-agricultural capital (which includes returns to self-employed labor in informal sector activities) are split between rural and urban households using as proxy the share of rural population in total population as informed by HIES (67\%). The split across rural households is made using shares of each household in reported incomes from non-farm enterprises, calculated using per capita earnings from the PRHS 2001-02 and household population totals from HIES. The remaining $33 \%$ of non-agricultural wage incomes are allocated between urban non-poor and poor households using an 85:15 ratio. 9 Returns to agricultural capital are split among households in proportion to their land income.

\footnotetext{
${ }^{8}$ Available from the authors upon request.

${ }^{9}$ Estimates of earnings from non-formal enterprises are perhaps the most uncertain figures in the SAM. Income data from the PRHS 2001-02 appear to seriously under-report these earnings for rural households. If per capita informal sector earnings from the PRHS 2001-02 are used as the basis for calculating total earnings in rural areas, the share of rural households in total informal
} 
In the absence of detailed information, public transfers and remittances to households informed in the Macro-SAM were allocated among households in proportion to their total expenditures.

Finally, regarding the uses of funds by households, final private consumption of each commodity was split among the 18 households using HIES 2007-08 to provide a prior. A relatively high (15\%) saving rate was used as a prior for medium/large farms and non-farm (quintiles 3 to 5) and a relatively low (7\%) saving rate was used as a prior for the remaining households except urban other (quintiles 3 to 5). Then, the prior saving rate of the urban other (quintiles 3 to 5 , which also captures enterprise savings) was determined residually from the domestic private saving figure in the Macro-SAM, generating a rate for this household group of $37.5 \%$.

\subsection{Balancing the Final Proto-SAM}

After a series of adjustments that reduced the imbalances at the household level to be less than $30 \%$ of the average between income and expenditure, we re-ran the software to generate a new SAM that minimizes the cross-entropy distance between the proto-SAM and the SAM imposing the series of controls present in the Macro-SAM, allowing the generation of a balanced SAM that is perfectly consistent with the Macro-SAM. 
Figure 2.3-Generation of household income matrix

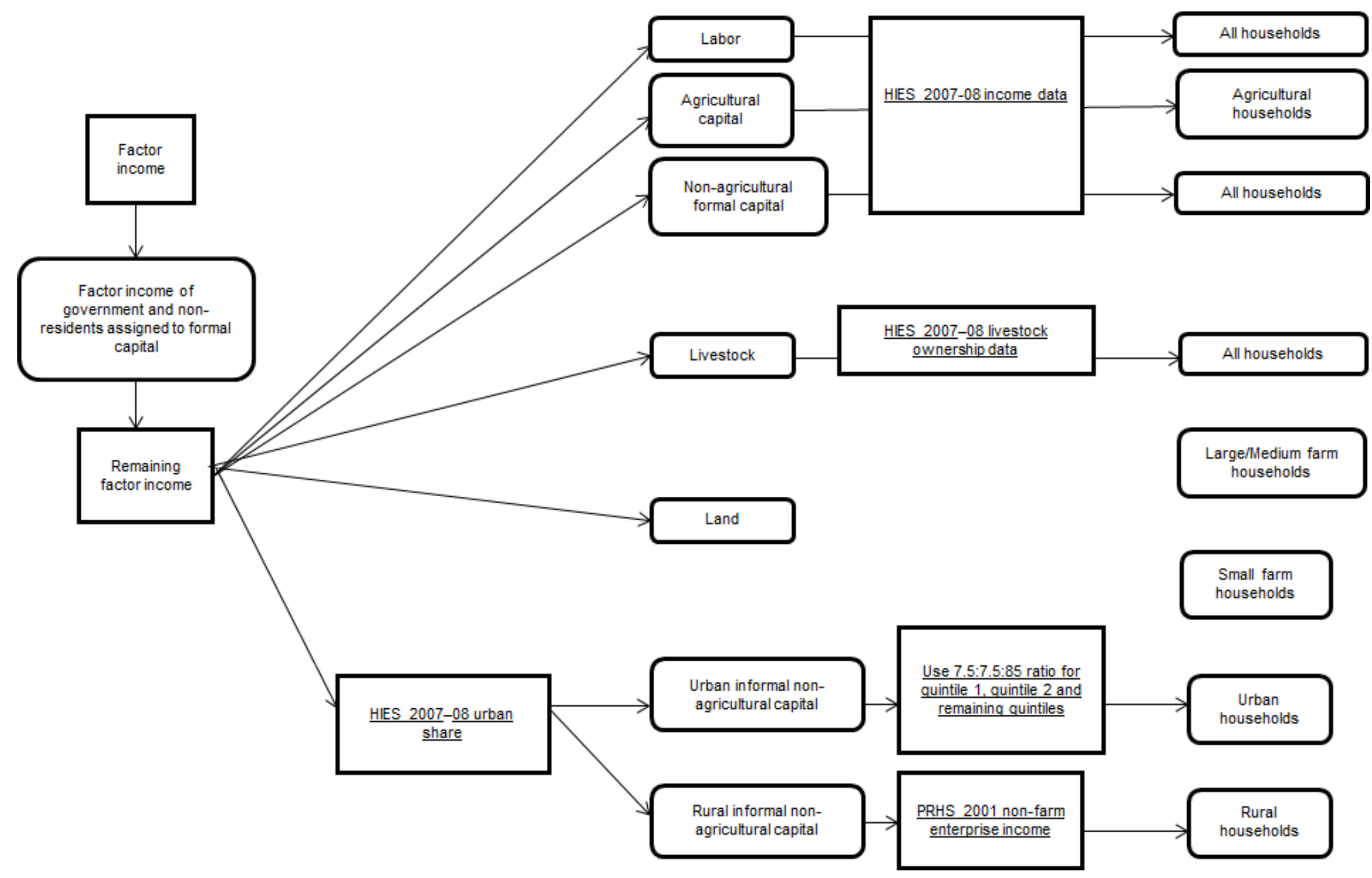




\section{STRUCTURE OF THE PAKISTAN ECONOMY: OBSERVATIONS FROM THE SAM}

The structure of value added (Table 3.1) is characteristic of a semi-industrialized economy, with a relatively low share of agriculture (20\%), and large shares of industry and services (27\% and $53 \%$, respectively). Livestock accounts for more than half of value added of the agricultural sector. Much of the industrial production is strongly linked to agriculture, including wheat, rice and sugar milling and textile production (linked to cotton). ${ }^{10}$ Trade (wholesale and retail) and transport generate more than half of the value added in services. Exports are a relatively low share of total output (6.5\%); imports are concentrated in the industrial sector (including petroleum products, part of the mining sector) and in private services (particularly, business services).

Table 3.I-Structure of the economy (percentages)

\begin{tabular}{|c|c|c|c|c|c|c|}
\hline & Output & $\begin{array}{l}\text { Value } \\
\text { added }\end{array}$ & Export & Import & $\begin{array}{l}\text { Export I } \\
\text { Output }\end{array}$ & $\begin{array}{c}\text { Import I } \\
\text { Domestic } \\
\text { absorption }\end{array}$ \\
\hline Agricultural Sector & 12.1 & 20.3 & 1.6 & 3.0 & 0.9 & 2.9 \\
\hline Crops & 5.7 & 8.9 & 0.8 & 2.8 & 0.9 & 5.7 \\
\hline Livestock & 5.9 & 10.6 & 0.2 & 0.2 & 0.2 & 0.4 \\
\hline Fishing & 0.4 & 0.5 & 0.7 & - & 12.5 & - \\
\hline Forestry & 0.1 & 0.3 & - & - & - & - \\
\hline Industrial Sector & 47.3 & 26.8 & 67.2 & 76.2 & 9.2 & 17.8 \\
\hline Mining and Quarrying & 2.6 & 3.0 & 0.0 & 10.7 & 0.0 & 33.4 \\
\hline Manufacturing & 38.9 & 19.7 & 67.2 & 65.5 & 11.2 & 18.8 \\
\hline Electricity, Gas and Water Distribution & 1.2 & 1.5 & - & - & - & - \\
\hline Construction & 4.6 & 2.6 & - & - & - & - \\
\hline Services Sector & 40.7 & 52.9 & 31.1 & 20.8 & 4.9 & 6.2 \\
\hline Wholesale and Retail & 10.3 & 18.4 & 0.1 & 0.6 & 0.1 & 0.7 \\
\hline Transport and Communication & 14.0 & 11.7 & 14.9 & - & 6.8 & - \\
\hline Ownership of Dwellings & 1.3 & 2.4 & - & - & - & - \\
\hline Public Administration and Defense & 5.9 & 5.3 & - & - & - & - \\
\hline Social, Community and Private Services & 6.7 & 9.4 & 16.1 & 20.2 & 15.6 & 30.5 \\
\hline Financial Services & 2.5 & 5.6 & - & - & - & - \\
\hline Total & 100.0 & 100.0 & 100.0 & 100.0 & 6.5 & 11.6 \\
\hline
\end{tabular}

Source: SAM for Pakistan

Table 3.2 below shows the composition of value added across sectors. For agricultural products, land is the largest component of value added. Manufacturing activities depend heavily on formal capital, while labor and other capital are important for most services. A more disaggregated composition is shown in Appendix 4.

Table 3.2-Composition of Value Added (Total column in billions of Pakistan rupees, rest in percentage)

\begin{tabular}{|c|c|c|c|c|c|c|c|}
\hline & Land & Labor & $\begin{array}{l}\text { Live } \\
\text { stock }\end{array}$ & $\begin{array}{l}\text { Formal } \\
\text { Capital }\end{array}$ & $\begin{array}{l}\text { Other } \\
\text { Capital }\end{array}$ & $\begin{array}{c}\text { Total } \\
(\%)\end{array}$ & $\begin{array}{c}\text { Total Value } \\
\text { Added }\end{array}$ \\
\hline Agricultural Sector & 28.6 & 15.9 & 37.8 & 11.4 & 6.3 & 100.0 & 1986.8 \\
\hline Crops & 63.5 & 27.0 & 0.0 & 0.0 & 9.5 & 100.0 & 882.9 \\
\hline Livestock & 0.0 & 6.7 & 72.6 & 20.7 & 0.0 & 100.0 & 1051.4 \\
\hline Fishing & 0.0 & 18.3 & 0.0 & 23.4 & 58.4 & 100.0 & 52.4 \\
\hline Forestry & 50.0 & 5.7 & 0.0 & 0.0 & 44.3 & 100.0 & 30.4 \\
\hline Industrial Sector & 0.0 & 25.9 & 0.0 & 60.7 & 13.5 & 100.0 & 2658.2 \\
\hline Mining and Quarrying & 0.0 & 72.0 & 0.0 & 28.0 & 0.0 & 100.0 & 301.5 \\
\hline Manufacturing & 0.0 & 16.9 & 0.0 & 68.4 & 14.7 & 100.0 & 1950.5 \\
\hline Electricity, Gas and Water Distribution & 0.0 & 15.6 & 0.0 & 84.4 & 0.0 & 100.0 & 145.9 \\
\hline Construction & 0.0 & 45.4 & 0.0 & 27.3 & 27.3 & 100.0 & 260.3 \\
\hline Services Sector & 0.0 & 26.7 & 0.0 & 24.6 & 48.6 & 100.0 & 5246.2 \\
\hline Wholesale and Retail & 0.0 & 8.9 & 0.0 & 27.3 & 63.8 & 100.0 & 1829.9 \\
\hline Transport and Communication & 0.0 & 24.2 & 0.0 & 22.7 & 53.1 & 100.0 & 1155.9 \\
\hline Ownership of Dwellings & 0.0 & 8.9 & 0.0 & 30.2 & 60.9 & 100.0 & 239.0 \\
\hline Public Administration and Defense & 0.0 & 64.2 & 0.0 & 35.8 & 0.0 & 100.0 & 530.1 \\
\hline $\begin{array}{l}\text { Social, Community and Private } \\
\text { Services }\end{array}$ & 0.0 & 49.9 & 0.0 & 15.0 & 35.1 & 100.0 & 934.6 \\
\hline Financial Services & 0.0 & 23.7 & 0.0 & 22.9 & 53.4 & 100.0 & 556.7 \\
\hline
\end{tabular}

Source: SAM for Pakistan

\footnotetext{
${ }^{10}$ Not tabulated.
} 
Large and medium farmers of Pakistan earn a large share of their income from land (Table 3.3). However, small and landless farmers rely on labor, livestock, and other capital for most of their income. Rural non-farm and urban households mostly rely on their labor and other capital as the sources of income.

Table 3.3-Household Income Shares (Total income column in billions of Pakistan rupees, rest in percentage)

\begin{tabular}{|c|c|c|c|c|c|c|c|c|c|}
\hline & Land & Labor & $\begin{array}{l}\text { Live } \\
\text { stock }\end{array}$ & $\begin{array}{l}\text { Formal } \\
\text { capital }\end{array}$ & $\begin{array}{l}\text { Other } \\
\text { capital }\end{array}$ & $\begin{array}{c}\text { Govern } \\
\text { ern- } \\
\text { ment }\end{array}$ & $\begin{array}{l}\text { Non- } \\
\text { residents }\end{array}$ & Total (\%) & $\begin{array}{c}\text { Total } \\
\text { income }\end{array}$ \\
\hline $\begin{array}{l}\text { Large \& Medium farm - } \\
\text { Sindh }\end{array}$ & 57.7 & 11.0 & 7.4 & 0.0 & 16.0 & 4.8 & 3.2 & 100.0 & 160.4 \\
\hline $\begin{array}{l}\text { Large \& Medium farm - } \\
\text { Punjab }\end{array}$ & 31.8 & 9.2 & 14.0 & 0.0 & 37.3 & 4.2 & 3.5 & 100.0 & 652.6 \\
\hline $\begin{array}{l}\text { Large \& Medium farm - } \\
\text { Other }\end{array}$ & 42.5 & 19.7 & 4.2 & 0.0 & 27.9 & 2.8 & 3.0 & 100.0 & 89.6 \\
\hline Small farm - Sindh & 15.1 & 12.2 & 18.4 & 0.0 & 37.6 & 8.5 & 8.3 & 100.0 & 192.2 \\
\hline Small farm - Punjab & 11.4 & 9.6 & 24.1 & 0.0 & 39.0 & 7.8 & 8.1 & 100.0 & $1,223.0$ \\
\hline Small farm - Other & 9.3 & 16.9 & 11.1 & 0.0 & 47.9 & 7.0 & 7.9 & 100.0 & 348.8 \\
\hline Landless Farmer - Sindh & 11.5 & 10.0 & 21.1 & 0.0 & 41.8 & 7.0 & 8.5 & 100.0 & 144.7 \\
\hline $\begin{array}{l}\text { Landless Farmer - } \\
\text { Punjab }\end{array}$ & 8.2 & 13.9 & 37.1 & 0.0 & 25.5 & 7.3 & 8.0 & 100.0 & 193.3 \\
\hline Landless Farmer - Other & 5.7 & 16.5 & 18.1 & 0.0 & 43.8 & 7.1 & 8.6 & 100.0 & 79.9 \\
\hline $\begin{array}{l}\text { Landless Agricultural } \\
\text { Laborers - Sindh }\end{array}$ & 0.0 & 21.7 & 3.5 & 0.0 & 59.7 & 6.6 & 8.6 & 100.0 & 155.5 \\
\hline $\begin{array}{l}\text { Landless Agricultural } \\
\text { Laborers - Punjab }\end{array}$ & 0.0 & 21.0 & 11.9 & 0.0 & 53.4 & 6.1 & 7.7 & 100.0 & 148.0 \\
\hline $\begin{array}{l}\text { Landless Agricultural } \\
\text { Laborers - Other }\end{array}$ & 0.0 & 33.7 & 1.8 & 0.0 & 49.8 & 6.3 & 8.4 & 100.0 & 19.1 \\
\hline Rural non-farm quintile 1 & 0.0 & 36.1 & 6.7 & 0.0 & 46.3 & 4.9 & 6.0 & 100.0 & 295.9 \\
\hline Rural non-farm quintile 2 & 0.0 & 38.9 & 8.5 & 0.0 & 39.3 & 6.1 & 7.3 & 100.0 & 351.6 \\
\hline Rural non-farm other & 0.0 & 36.3 & 5.4 & 0.0 & 42.7 & 7.3 & 8.3 & 100.0 & $1,831.9$ \\
\hline Urban quintile 1 & 0.0 & 59.8 & 0.0 & 0.0 & 25.3 & 6.9 & 8.0 & 100.0 & 277.8 \\
\hline Urban quintile 2 & 0.0 & 63.2 & 0.0 & 0.0 & 21.2 & 7.2 & 8.4 & 100.0 & 356.3 \\
\hline Urban other & 0.0 & 16.8 & 0.0 & 59.7 & 12.2 & 4.4 & 6.9 & 100.0 & $4,084.9$ \\
\hline Rural farm sub-total & 16.9 & 12.3 & 18.1 & 0.0 & 39.2 & 6.6 & 6.9 & 100.0 & $3,407.0$ \\
\hline Rural non-farm sub-total & 0.0 & 36.7 & 6.0 & 0.0 & 42.7 & 6.8 & 7.9 & 100.0 & $2,479.3$ \\
\hline Urban subtotal & 0.0 & 22.9 & 0.0 & 51.7 & 13.6 & 4.8 & 7.1 & 100.0 & $4,719.0$ \\
\hline Total households & 5.4 & 22.7 & 7.2 & 23.0 & 28.6 & 5.8 & 7.2 & 100.0 & $10,605.3$ \\
\hline
\end{tabular}

Source: SAM for Pakistan

The importance of agricultural income by household group is generally lower in the recent SAM than in the Permanent Rural Household Survey (PRHS) of 2001-02, suggesting that households have more diversified income sources than as suggested by PRHS data (Table 3.4). The SAM shows that agricultural income accounts for a large share of income for all farmers, especially for the medium and large farms (66\% of their total income), consistent with the PRHS data.

Table 3.4-Rural agricultural incomes

\begin{tabular}{lcc} 
Household group & $\begin{array}{c}\text { Share of } \\
\text { agricultural } \\
\text { income in PRHS }\end{array}$ & $\begin{array}{c}\text { Share of } \\
\text { agricultural } \\
\text { income in SAM }\end{array}$ \\
\hline Medium and large farms & 83.5 & 66.0 \\
Small farms & 67.9 & 41.2 \\
Landless farmers & 87.7 & 45.6 \\
Rural agricultural workers & 53.1 & 22.2 \\
Rural non-farm non-poor & 1.9 & 6.7 \\
Rural non-farm poor & 6.3 & 9.7 \\
Rural agricultural & 74.8 & 46.5 \\
Rural & 69.7 & 30.1 \\
\hline
\end{tabular}

Source: PRHS 2001-02 and 2008 Pakistan SAM.

\section{INCOME MULTIPLIER ANALYSES}

To illustrate the use of the SAM, we use income multiplier analysis. A survey of income multiplier analysis methods and findings can be found in Haggblade, Hazell, and Reardon (2007). To capture the production and consumption linkages, taking into account the supply-rigidities present in Pakistan, we use a semi-input-output model, with constrained linear relationships among quantities in the model and fixed prices. In this approach, sectors are classified into two groups: those that are supply constrained and those that are supply-responsive. Output responses are permitted only in supply-responsive 
sectors. For these models to produce a suitable approximation of reality, the supply-constrained sectors must correspond to tradable goods whose domestic supply remains fixed at the prevailing output price. Therefore, we follow this approach. In the supply-constrained sectors, imbalances between supply and demand are equilibrated via changes in net exports.

The starting point is the sector-specific equilibrium conditions, i.e. $x_{c}\left(1+t c_{c}\right)=\sum_{c^{\prime}} z_{c c^{\prime}}+\sum_{h} c_{c h}+g_{c}+i_{c}+e_{c}$, where $x_{c}$ is pre-commodity-tax gross output, $t c_{c}$ is commodity tax rate, $z_{c c}$ is intermediate demand of good $c$ by sector $c^{\prime}, c_{c h}$ is household consumption of good $c$ by household $h, g_{c}$ is public consumption of good $c, i_{c}$ is investment (fixed and change in stock) demand for good $c$, and $e_{c}$ is net export of good $c$. Intermediate and factor demand are assumed to be proportional to output production, i.e. $z_{c c^{\prime}}=a_{c c^{\prime}} x_{c^{\prime}}$ and $v_{f c^{\prime}}=a_{f c^{\prime}} x_{c^{\prime}}$, where $a_{c c^{\prime}}$ and $a_{f c^{\prime}}$ are the requirements of intermediate input $c^{\prime}$ and factor $f$ to produce a unit of $c$. Household consumption is given by $c_{c h}=\theta_{c h}\left(1-t h_{h}\right) y_{h}$, where $y_{h}$ is pre-tax income of household $h, t h_{h}$ is the corresponding tax rate, and $\theta_{c h}$ is the share of post-tax income of household $h$ spent on commodity $c$. Finally, pre-tax household income is the sum of factor income and transfers received by the household from other agents, i.e. $y_{h}=\sum_{f} a_{h f} v_{f}+t r_{h}$, with $v_{f}=\sum_{c} v_{f c}$, and $a_{h f}$ being the share of household $h$ in the income of factor $f$.

Replacing the intermediate and factor demand and household demand function into the equilibrium condition, we find that $x_{c}\left(1+t c_{c}\right)=\sum_{c^{\prime}}\left(a_{c c^{\prime}} x_{c^{\prime}}\right)+\sum_{h}\left\{\theta_{c h}\left(1-t h_{h}\right)\left[\sum_{f}\left(a_{h f}\left(\sum_{c^{\prime}} a_{f c^{\prime}} x_{c^{\prime}}\right)\right)+t r_{h}\right]\right\}+g_{c}+i_{c}+e_{c}{ }^{11}$, which can be solved either for $x_{c}$ (demand-constrained sector) or for $e_{c}$ (supply-constrained sector), fixing either $e_{c}$ (demand-constrained sector) or $x_{c}$ (supply-constrained sector).

We conduct a series of simulations where a constant injection is applied to the economy (100 billion rupees during the year), either to supply (supply-constrained sector) or to net export demand (remaining sectors). We run a simulation focusing the injection only in crops (SIMC), where each crop receives a proportion of total injection given by its share in the total value added of crops. We then do the same for livestock (SIML), for industry (SIMI), for services (SIMS), and for all sectors (SIMA). Finally, we divided the absolute changes in output values by the injection, getting to the following output multipliers (Table 4.1). All aggregate output multipliers are in the 1.1-1.4 range, with livestock and industry having the highest output multipliers. These multipliers are significantly below the ones found for India by Pal, Pohit, and Roy (2012), probably reflecting that the mentioned analysis assumes the absence of supply rigidities, which we seek to capture here, but aligned with the 1.5 value added-multiplier reported in Dorosh, Niazi, and Nazli (2003), Haggblade, Hammer, and Hazell (1991), and Mellor (1995). As expected, the output multipliers are largest in the sector in which the injection takes place (main diagonal of the table). We also see that the direct effects are larger than the indirect, and that most of the indirect effects are concentrated into the services sectors. ${ }^{12}$ Finally, the injection into the services sector has the lowest output multiplier for the entire economy.

Table 4.I-Output Multipliers

\begin{tabular}{llllll} 
& SIMC & SIML & SIMI & SIMS & SIMA \\
\hline Crops & 1.007 & 0.054 & 0.053 & 0.000 & 0.110 \\
Livestock & 0.004 & 0.991 & 0.003 & 0.005 & 0.109 \\
\hline Industry & 0.139 & 0.020 & 1.049 & 0.024 & 0.308 \\
Services & 0.077 & 0.259 & 0.226 & 1.135 & 0.696 \\
TOTAL & 1.227 & 1.324 & 1.337 & 1.165 & 1.233 \\
\hline
\end{tabular}

Source: Authors' elaboration.

\section{CONCLUSIONS}

This paper presented the Social Accounting Matrix (SAM) of Pakistan for the year 2007-08, which seeks to support the continuing need to use recent and consistent multi-sectoral economic data for policy analysis and the development of economy-wide models (Robinson et al., 2001). In particular, it is expected to become a vital part of the Pakistan Strategy Support Program (PSSP) run by the International Food Policy Research Institute (IFPRI), which supports the Government of Pakistan with evidence-based policy reform for pro-poor economic growth and enhanced food security. The presented approach to estimating this SAM is motivated by an information theoretic approach to estimation (Judge \& Mittelhammer, 2012) that takes a Bayesian perspective on the efficient use of information: "Use all the information you have, but do not

\footnotetext{
${ }^{11}$ Transaction costs are captured in the application but are ignored here to avoid cluttering the explanation.

12 The only exception is the injection in crops, with the largest indirect effect placed in industry.
} 
assume any information you do not have." The presented SAM will be used with Computable General Equilibrium (CGE) models to analyze the impact of policy changes throughout the economy of Pakistan. It combines both input-output and national income and product accounts, supplemented by other information from a variety of sources and uses a "crossentropy" approach to balance the accounts. This SAM allows specification of a prior estimate of the mean and standard error of selected cell entries (expressed either as values or column coefficients), column sums, and macro aggregates, providing an updated and consistent database that is fully consistent with macroeconomic-level data and that is highly disaggregated, allowing for detailed macroeconomic and distributional analysis of relevant events.

The SAM highlights a series of relevant characteristics of the Pakistan economy. The livestock (10.5\% of the economy) and trade sectors (18.4\% of the economy) are shown to be significant contributors to the total domestic value added. For agricultural products, land is, unsurprisingly, the biggest component of value added. Manufacturing activities depend heavily on formal capital, while labor and other capital are important for most services. Large and medium farmers of Pakistan earn a large share of their income from land. However, small and landless farmers rely on labor, livestock, and other capital for most of their income. Rural non-farm and urban households mostly rely on their labor and other capital as income sources. To illustrate the use of the SAM, we conduct income multiplier analysis. In particular, to capture the production and consumption linkages, taking into account the supply-rigidities present in Pakistan, we use the semi-input-output model. All aggregate output multipliers turn out to be in the 1.1-1.4 range, with livestock and industry having the highest output multipliers. These multipliers are significantly below the ones found for India by Pal et al. (2012), probably reflecting that the mentioned analysis assumes the absence of supply rigidities, which we seek to capture here. The multipliers are, however, aligned with the 1.5 value added-multiplier reported in Dorosh et al. (2003) and others. Results suggest that the direct effects are larger than the indirect and that most of the indirect effects are concentrated into the services sectors. ${ }^{13}$ Finally, the injection into the services sector has the lowest output multiplier for the entire economy.

${ }^{13}$ The only exception is the injection in crops, with the largest indirect effect placed in industry. 


\section{APPENDIX}

Appendix I: Sectors in the Input-Output Matrix

\begin{tabular}{|c|c|c|c|}
\hline 1 & Crops: Rice (Paddy) & 42 & MF: Refined petroleum \\
\hline 2 & Crops: Wheat & 43 & MF: Rubber and plastic products \\
\hline 3 & Crops: Cotton (seed cotton) & 44 & MF: Other chemicals \\
\hline 4 & Crops: Sugar cane & 45 & MF: Bricks, tiles \\
\hline 5 & Crops: Tobacco & 46 & MF: Cement \\
\hline 6 & Crops: Other crops & 47 & MF: Other non-metallic mineral products \\
\hline 7 & Crops: Pulses and grams & 48 & MF: Basic metal products \\
\hline 8 & Crops: Potatoes & 49 & MF: Other metal products \\
\hline 9 & Crops: Fruits & 50 & MF: Other non-electrical machinery \\
\hline 10 & Crops: Vegetables and other condiments & 51 & MF: Electrical equipment etc. \\
\hline 11 & Crops: Oil seeds & 52 & MF: Other transport equipment \\
\hline 12 & Crops: Other & 53 & MF: Surgical instruments \\
\hline 13 & Livestock & 54 & MF: Handicrafts \\
\hline 14 & Forestry & 55 & MF: Sports goods \\
\hline 15 & Fisheries & 56 & MF: Jewelry (precious metal) \\
\hline 16 & Mining- Coal & 57 & MF: Other manufacturing products \\
\hline 17 & Mining- Crude oil and natural gas & 58 & Electricity and water works \\
\hline 18 & Mining- Other minerals & 59 & Gas supply \\
\hline 19 & MF: Vegetable oils etc. & 60 & Construction: Buildings and land improvement \\
\hline 20 & MF: Milling & 61 & Trade: Wholesale \\
\hline 21 & MF: Bakery products & 62 & Trade: Retail \\
\hline 22 & MF: Sugar & 63 & Hotel and restaurant services \\
\hline 23 & MF: Other food products & 64 & Transport: Railway \\
\hline 24 & MF: Beverages & 65 & Transport: Road \\
\hline 25 & MF: Cigarettes, tobacco & 66 & Transport: Water \\
\hline 26 & MF: Ginned cotton (lint) & 67 & Transport: Air \\
\hline 27 & MF: Cotton yarn & 68 & Transport: Other and storage \\
\hline 28 & MF: Cotton cloth & 69 & Communication services \\
\hline 29 & MF: Art silk & 70 & Banking: Central Monetary Authority \\
\hline 30 & MF: Made-up textile goods & 71 & Banking: Other Monetary institutions \\
\hline 31 & MF: Knitwear & 72 & Banking: Other Credit institutions \\
\hline 32 & MF: Carpets & 73 & Banking: Nominal product \\
\hline 33 & MF: Garments & 74 & Insurance \\
\hline 34 & MF: Other textile products & 75 & Real estate services \\
\hline 35 & MF: Leather, leather products & 76 & Imputed rent (owner-occupied dwellings) \\
\hline 36 & MF: Foot wear & 77 & Business services \\
\hline 37 & MF: Wood, wooden products, furniture & 78 & Public administration and defense \\
\hline 38 & MF: Paper, paper products & 79 & Education \\
\hline 39 & MF: Pharmaceutics & 80 & Health care \\
\hline 40 & MF: Fertilizers and pesticides & 81 & Other social and cultural services \\
\hline 41 & MF: Chemicals: Consumer products & 82 & Personal and household services \\
\hline
\end{tabular}


Appendix 2: Map from sectors in IO to those in SAM

\begin{tabular}{|c|c|c|c|}
\hline Sectors in 1091 & SAM 2007-08 sectors & Sectors in 1091 & SAM 2007-08 sectors \\
\hline 2 & Wheat (Irrigated) & 66 & Water Transport \\
\hline 2 & Wheat (Non-irrigated) & 67 & Air Transport \\
\hline 1 & Rice (Irri) & 68 & Other Transport \\
\hline 1 & Rice (Basmati) & 75 & Housing \\
\hline 3 & Cotton & 76 & Imputed Rent \\
\hline 4 & Sugarcane & 77 & Business Services \\
\hline $6,7,11,12$ & Other Field Crops & 80 & Health care \\
\hline $8,9,10$ & Fruits and Vegetables & 79 & Education \\
\hline 13 & Livestock (cattle, milk) & 82 & Personal Services \\
\hline 13 & Livestock (poultry) & 81 & Other Private Services \\
\hline 14 & Forestry & 70,78 & Public Services \\
\hline 15 & Fishing & \multirow[t]{28}{*}{$71,72,74$} & \multirow[t]{28}{*}{ Finance and Insurance } \\
\hline $16,17,18$ & Mining & & \\
\hline 19 & Vegetable oils & & \\
\hline 20 & Wheat Milling & & \\
\hline 20 & Rice Milling (Irri) & & \\
\hline 20 & Rice Milling (Basmati) & & \\
\hline 22 & Sugar & & \\
\hline $5,21,23,24,25$ & Other Food & & \\
\hline 26 & Cotton gin (lint) & & \\
\hline 27 & Cotton spin (yarn) & & \\
\hline 28 & Cotton weave (cloth) & & \\
\hline 31 & Knitwear & & \\
\hline $32,33,34$ & Garments & & \\
\hline 29,30 & Other Textiles & & \\
\hline 35,36 & Leather & & \\
\hline 37 & Wood & & \\
\hline $39,41,44$ & Chemicals & & \\
\hline 40 & Fertilizers & & \\
\hline 45,46 & Cement and Bricks & & \\
\hline 42 & Petroleum refining & & \\
\hline $38,43,47-57$ & Other Manufacturing & & \\
\hline 58,59 & Energy & & \\
\hline 60 & Construction & & \\
\hline 61 & Wholesale Trade & & \\
\hline 62 & Retail Trade & & \\
\hline 63 & Other Trade & & \\
\hline 64,69 & Railway Transport & & \\
\hline 65 & Road Transport & & \\
\hline
\end{tabular}


Appendix 3: Map from commodities in HIES household survey to sectors in the SAM

\section{Commodities of HIES}

SAM 2007-08 commodities

\begin{tabular}{|c|c|}
\hline 2103-2104, 2201-2206 & Other Field Crops \\
\hline 1301-1308, 1501-1510 & Fruits and Vegetables \\
\hline $1101-1103,1201-1202$ & Livestock (cattle, milk) \\
\hline $1203-1204$ & Livestock (poultry) \\
\hline 1205 & Fish \\
\hline $2301-2303$ & Vegetable oils \\
\hline $2101,2502,2503$ & Wheat Flour \\
\hline Part of 2102 & Rice (Irri) \\
\hline Part of 2102 & Rice (Basmati) \\
\hline 1701 & Sugar \\
\hline $1803,2105,2501,2504,2601$ & Other Food \\
\hline 6103 & Cotton cloth \\
\hline 5103 & Knitwear \\
\hline 5101-5102, 5104-5105 & Garments \\
\hline 6102,6104 & Other Textiles \\
\hline $5201-5202$ & Leather \\
\hline 2701 & Wood \\
\hline 5601 & Chemicals \\
\hline 4301 & Petroleum \\
\hline $6101,6302-6303,6305,6401,6403-6404$ & Other Manufacturing goods \\
\hline 2702-2707, 2709 & Energy \\
\hline 2406 & Construction \\
\hline 4303 & Railway Transport \\
\hline $4302,4304,6505$ & Road Transport \\
\hline 5705 & Air Transport \\
\hline $5401-5402,5405$ & Housing \\
\hline $5403-5404$ & Imputed Rent \\
\hline 5602 & Health Care \\
\hline $5801-5804$ & Education \\
\hline $2901-2903$ & Personal Services \\
\hline $4401,5903-5904$ & Other Private Services \\
\hline
\end{tabular}


Appendix 4.A: Distribution of factor payments among agricultural activities

\begin{tabular}{|c|c|c|c|c|c|c|c|c|c|c|c|c|c|}
\hline & 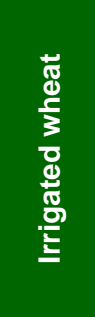 & 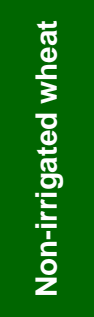 & 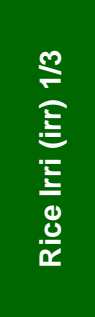 & 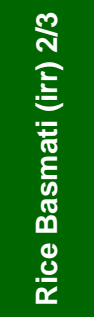 & $\begin{array}{l}\text { 을 } \\
\text { ᄃ } \\
\text { 릉 } \\
0\end{array}$ & 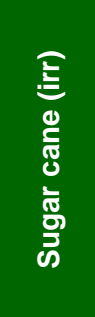 & $\begin{array}{l}\frac{0}{0} \\
\frac{0}{0} \\
\frac{0}{0} \\
\frac{0}{4} \\
\frac{}{2} \\
\frac{2}{5}\end{array}$ & 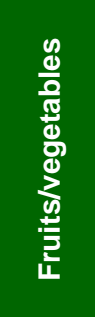 & 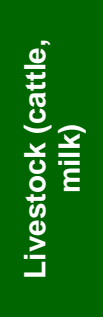 & 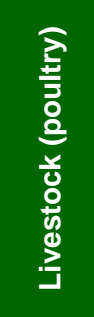 & 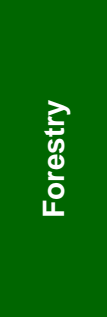 & $\begin{array}{l}\text { D } \\
\frac{D}{2} \\
\text { 足 }\end{array}$ & $\begin{array}{l}\text { 올 } \\
\text { 焉 }\end{array}$ \\
\hline Labor - agric (own)-large & 3.4 & 4.6 & 2.1 & 0.6 & 3.6 & 1.8 & 3.8 & 0.3 & 0.0 & 0.0 & 1.2 & 0.0 & 0.0 \\
\hline Labor - agric (own)-med Sindh & 1.4 & 0.1 & 2.2 & 0.2 & 1.7 & 0.8 & 3.7 & 0.7 & 0.0 & 0.0 & 0.1 & 0.0 & 0.0 \\
\hline Labor - agric (own)-med Punjab & 3.4 & 8.3 & 1.9 & 2.3 & 7.8 & 2.4 & 5.2 & 2.9 & 0.0 & 0.0 & 0.5 & 0.0 & 0.0 \\
\hline Labor - agric (own)-med OPak & 4.9 & 4.9 & 0.6 & 0.1 & 0.1 & 0.2 & 1.3 & 0.3 & 0.0 & 0.0 & 1.2 & 0.0 & 0.0 \\
\hline Labor - agric (own)-sm Sindh & 2.5 & 0.3 & 3.8 & 0.4 & 3.4 & 1.2 & 3.0 & 1.8 & 0.0 & 0.0 & 0.1 & 0.0 & 0.0 \\
\hline Labor - agric (own)-sm Punjab & 10.8 & 15.3 & 2.6 & 4.4 & 9.8 & 3.2 & 6.1 & 8.1 & 0.0 & 0.0 & 0.5 & 0.0 & 0.0 \\
\hline Labor - agric (own)-sm OPak & 1.6 & 15.1 & 0.6 & 0.1 & 0.0 & 0.9 & 5.1 & 1.8 & 0.0 & 0.0 & 1.2 & 0.0 & 0.0 \\
\hline Labor - agric (wage) & 6.5 & 11.3 & 3.2 & 1.9 & 6.2 & 2.5 & 6.6 & 3.7 & 6.7 & 6.7 & 1.1 & 18.3 & 0.0 \\
\hline Labor - non-ag (unsk) & 0.0 & 0.0 & 0.0 & 0.0 & 0.0 & 0.0 & 0.0 & 0.0 & 0.0 & 0.0 & 0.0 & 0.0 & 10.8 \\
\hline Labor - non-ag (skilled) & 0.0 & 0.0 & 0.0 & 0.0 & 0.0 & 0.0 & 0.0 & 0.0 & 0.0 & 0.0 & 0.0 & 0.0 & 61.2 \\
\hline Land - large- Sindh & 1.0 & 0.0 & 4.8 & 0.6 & 1.8 & 5.5 & 0.8 & 0.3 & 0.0 & 0.0 & 0.5 & 0.0 & 0.0 \\
\hline Land - large- Punjab & 2.6 & 1.7 & 3.1 & 4.3 & 4.7 & 5.5 & 5.9 & 1.0 & 0.0 & 0.0 & 3.5 & 0.0 & 0.0 \\
\hline Land - large - OthPak & 0.7 & 1.1 & 2.2 & 0.1 & 0.1 & 0.8 & 0.0 & 0.0 & 0.0 & 0.0 & 8.5 & 0.0 & 0.0 \\
\hline Land - irrigated - med Sindh & 1.7 & 0.0 & 10.9 & 1.5 & 3.1 & 5.4 & 6.5 & 2.5 & 0.0 & 0.0 & 0.0 & 0.0 & 0.0 \\
\hline Land - irrigated - med Punjab & 4.2 & 0.0 & 9.1 & 20.0 & 14.3 & 15.8 & 9.1 & 10.8 & 0.0 & 0.0 & 0.0 & 0.0 & 0.0 \\
\hline Land - irrigated - med OthPak & 6.1 & 0.0 & 3.1 & 0.8 & 0.1 & 1.6 & 2.4 & 1.2 & 0.0 & 0.0 & 0.0 & 0.0 & 0.0 \\
\hline Land - irrigated - sm Sindh & 3.2 & 0.0 & 18.7 & 3.5 & 6.3 & 7.7 & 5.3 & 6.6 & 0.0 & 0.0 & 0.0 & 0.0 & 0.0 \\
\hline Land - irrigated - sm Punjab & 13.4 & 0.0 & 12.5 & 37.9 & 18.0 & 20.7 & 10.8 & 29.8 & 0.0 & 0.0 & 0.0 & 0.0 & 0.0 \\
\hline Land - irrigated - sm OthPak & 2.0 & 0.0 & 2.8 & 1.0 & 0.1 & 5.9 & 9.0 & 6.8 & 0.0 & 0.0 & 0.0 & 0.0 & 0.0 \\
\hline Land non-irrig - sm/m Sindh & 0.0 & 0.0 & 0.0 & 0.0 & 0.0 & 0.0 & 0.0 & 0.0 & 0.0 & 0.0 & 1.5 & 0.0 & 0.0 \\
\hline Land non-irrig - sm/m Punjab & 0.0 & 14.7 & 0.0 & 0.0 & 0.0 & 0.0 & 0.0 & 0.0 & 0.0 & 0.0 & 10.4 & 0.0 & 0.0 \\
\hline Land non-irrig - sm/m OthPak & 0.0 & 12.4 & 0.0 & 0.0 & 0.0 & 0.0 & 0.0 & 0.0 & 0.0 & 0.0 & 25.6 & 0.0 & 0.0 \\
\hline Water & 20.0 & 0.0 & 8.4 & 15.6 & 10.2 & 8.6 & 5.0 & 10.0 & 0.0 & 0.0 & 0.0 & 0.0 & 0.0 \\
\hline Capital livestock & 0.0 & 0.0 & 0.0 & 0.0 & 0.0 & 0.0 & 0.0 & 0.0 & 72.6 & 72.6 & 0.0 & 0.0 & 0.0 \\
\hline Capital other agric & 10.7 & 10.0 & 7.7 & 4.9 & 8.6 & 9.2 & 10.4 & 11.2 & 0.0 & 0.0 & 44.3 & 0.0 & 0.0 \\
\hline Capital formal & 0.0 & 0.0 & 0.0 & 0.0 & 0.0 & 0.0 & 0.0 & 0.0 & 20.7 & 20.7 & 0.0 & 23.4 & 28.0 \\
\hline Capital informal & 0.0 & 0.0 & 0.0 & 0.0 & 0.0 & 0.0 & 0.0 & 0.0 & 0.0 & 0.0 & 0.0 & 58.4 & 0.0 \\
\hline Total & 100.0 & 100.0 & 100.0 & 100.0 & 100.0 & 100.0 & 100.0 & 100.0 & 100.0 & 100.0 & 100.0 & 100.0 & 100.0 \\
\hline
\end{tabular}

Source: SAM for Pakistan 2007-08 
Appendix 4.B: Household incomes and expenditures, 2007-08

\begin{tabular}{|c|c|c|c|c|c|c|c|c|c|c|}
\hline & $\begin{array}{l}\text { SAM } \\
\text { Income } \\
\text { (Billion } \\
\text { Rs) }\end{array}$ & $\begin{array}{l}\text { Population } \\
\text { (Millions) }\end{array}$ & $\begin{array}{c}\text { SAM } \\
\text { Income } \\
\text { ICapita } \\
\text { (Thousand } \\
\text { Rs) }\end{array}$ & $\begin{array}{l}\text { Share of } \\
\text { Total } \\
\text { Income } \\
(\%)\end{array}$ & $\begin{array}{c}\text { Share of } \\
\text { Total } \\
\text { Population } \\
(\%)\end{array}$ & $\begin{array}{l}\text { HIES } \\
\text { Income } \\
\text { (Billion } \\
\text { Rs) }\end{array}$ & $\begin{array}{c}\text { HIES } \\
\text { Income } \\
\text { ICapita } \\
\text { (Thousand } \\
\text { Rs) }\end{array}$ & $\begin{array}{c}\text { HIES } \\
\text { Expendi- } \\
\text { ture (Billion } \\
\text { Rs) }\end{array}$ & $\begin{array}{c}\text { HIES } \\
\text { Expendi- } \\
\text { ture /Capita } \\
\text { (Thousand } \\
\text { Rs) }\end{array}$ & $\begin{array}{c}\text { SAM } \\
\text { Income } \\
\text { IHIES } \\
\text { Income } \\
\text { Ratio }\end{array}$ \\
\hline Large \& Medium farm - Sindh & 160.4 & 3.1 & 52.0 & 1.5 & 2.4 & 41.8 & 13.6 & 15.6 & 5.1 & 3.8 \\
\hline Large \& Medium farm - Punjab & 652.6 & 3.5 & 185.5 & 6.2 & 2.7 & 191.3 & 54.4 & 88.4 & 25.1 & 3.4 \\
\hline Large \& Medium farm - Other & 89.6 & 0.5 & 187.5 & 0.8 & 0.4 & 16.8 & 35.2 & 10.7 & 22.5 & 5.3 \\
\hline Small farm - Sindh & 192.2 & 0.7 & 272.1 & 1.8 & 0.5 & 61.4 & 86.9 & 54.0 & 76.5 & 3.1 \\
\hline Small farm - Punjab & 1223.0 & 2.2 & 567.7 & 11.5 & 1.6 & 417.4 & 193.8 & 406.6 & 188.7 & 2.9 \\
\hline Small farm - Other & 348.8 & 0.5 & 683.2 & 3.3 & 0.4 & 101.7 & 199.2 & 118.0 & 231.1 & 3.4 \\
\hline Landless Farmer - Sindh & 144.7 & 2.5 & 57.3 & 1.4 & 1.9 & 45.2 & 17.9 & 42.5 & 16.8 & 3.2 \\
\hline Landless Farmer - Punjab & 193.3 & 3.6 & 54.4 & 1.8 & 2.7 & 81.7 & 23.0 & 71.2 & 20.0 & 2.4 \\
\hline Landless Farmer - Other & 79.9 & 1.7 & 46.3 & 0.8 & 1.3 & 25.0 & 14.5 & 28.4 & 16.5 & 3.2 \\
\hline Landless Agricultural Laborers - Sindh & 155.5 & 3.1 & 49.4 & 1.5 & 2.4 & 36.3 & 11.5 & 56.4 & 17.9 & 4.3 \\
\hline \multicolumn{11}{|l|}{ Landless Agricultural Laborers - } \\
\hline Punjab & 148.0 & 16.0 & 9.3 & 1.4 & 12.2 & 32.9 & 2.1 & 59.9 & 3.7 & 4.5 \\
\hline Landless Agricultural Laborers - Other & 19.1 & 5.6 & 3.4 & 0.2 & 4.3 & 5.6 & 1.0 & 7.9 & 1.4 & 3.4 \\
\hline Rural non-farm quintile 1 & 295.9 & 9.0 & 33.1 & 2.8 & 6.9 & 105.4 & 11.8 & 62.1 & 6.9 & 2.8 \\
\hline Rural non-farm quintile 2 & 351.6 & 8.9 & 39.3 & 3.3 & 6.8 & 112.0 & 12.5 & 91.1 & 10.2 & 3.1 \\
\hline Rural non-farm other & 1831.9 & 26.8 & 68.2 & 17.3 & 20.6 & 575.9 & 21.5 & 529.6 & 19.7 & 3.2 \\
\hline Urban quintile 1 & 277.8 & 8.6 & 32.4 & 2.6 & 6.6 & 289.4 & 33.7 & 82.2 & 9.6 & 1.0 \\
\hline Urban quintile 2 & 356.3 & 8.6 & 41.6 & 3.4 & 6.6 & 138.6 & 16.2 & 115.7 & 13.5 & 2.6 \\
\hline Urban other & 4084.9 & 25.7 & 158.7 & 38.5 & 19.7 & 726.8 & 28.2 & 793.2 & 30.8 & 5.6 \\
\hline Rural farm sub-total & 3407.0 & 43.0 & 79.2 & 32.1 & 32.9 & 1057.2 & 24.6 & 959.7 & 22.3 & 3.2 \\
\hline Rural non-farm sub-total & 2479.3 & 44.7 & 55.4 & 23.4 & 34.2 & 793.2 & 17.7 & 682.8 & 15.3 & 3.1 \\
\hline Urban subtotal & 4719.0 & 42.9 & 110.1 & 44.5 & 32.8 & 1154.8 & 26.9 & 991.1 & 23.1 & 4.1 \\
\hline Total households & 10605.3 & 130.6 & 81.2 & 100.0 & 100.0 & 3005.3 & 23.0 & 2633.5 & 20.2 & 3.5 \\
\hline Rural poor household groups & 3151.9 & 53.8 & 58.6 & 29.7 & 41.2 & 1024.6 & 19.0 & 998.0 & 18.5 & 3.1 \\
\hline
\end{tabular}

Source: SAM for Pakistan 2007-08, HIES 2007-08 
Appendix 4.C: Distribution of total land income in Pakistan

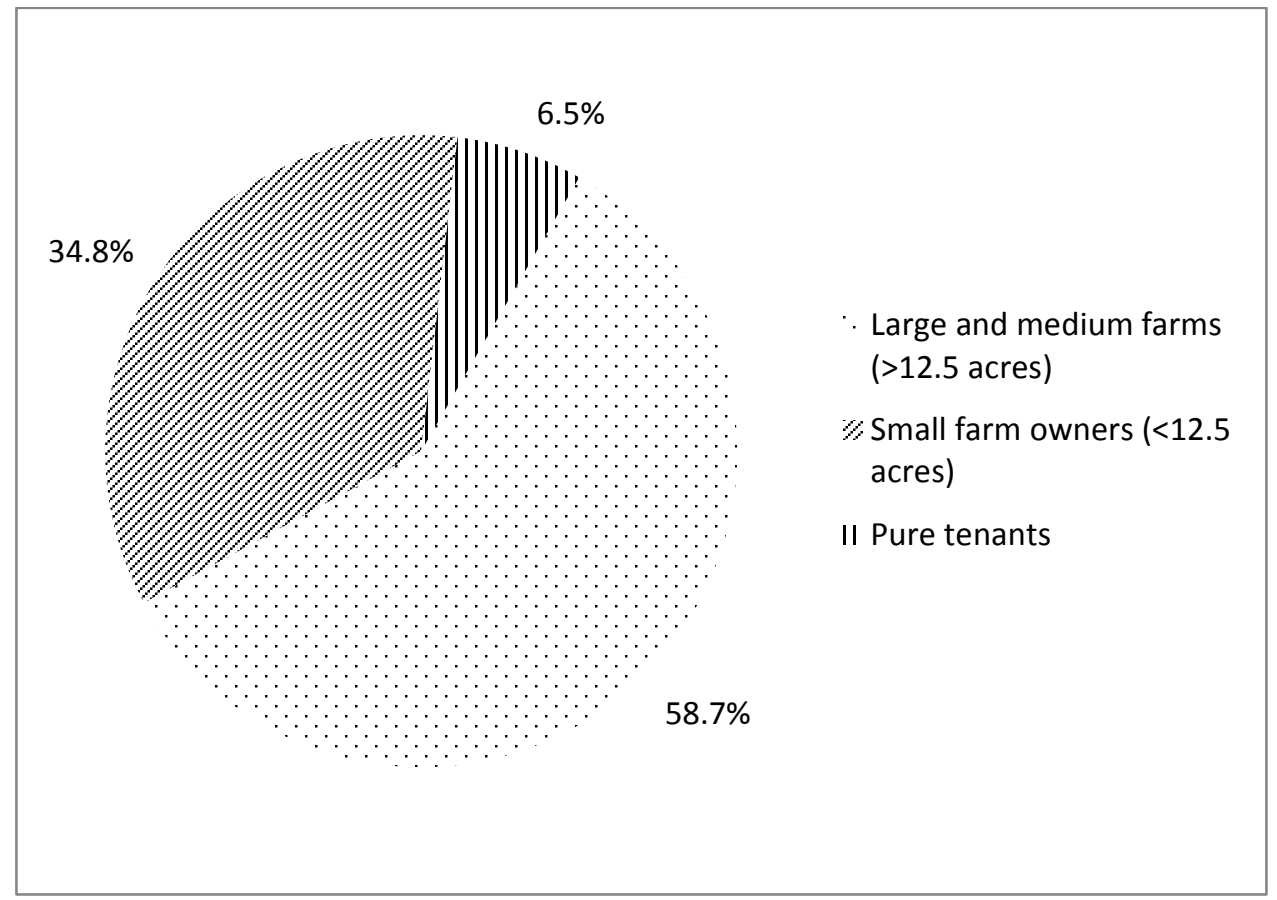

Source: SAM for Pakistan 2007-08

Appendix 4.D: Poverty in Pakistan, 2007-08

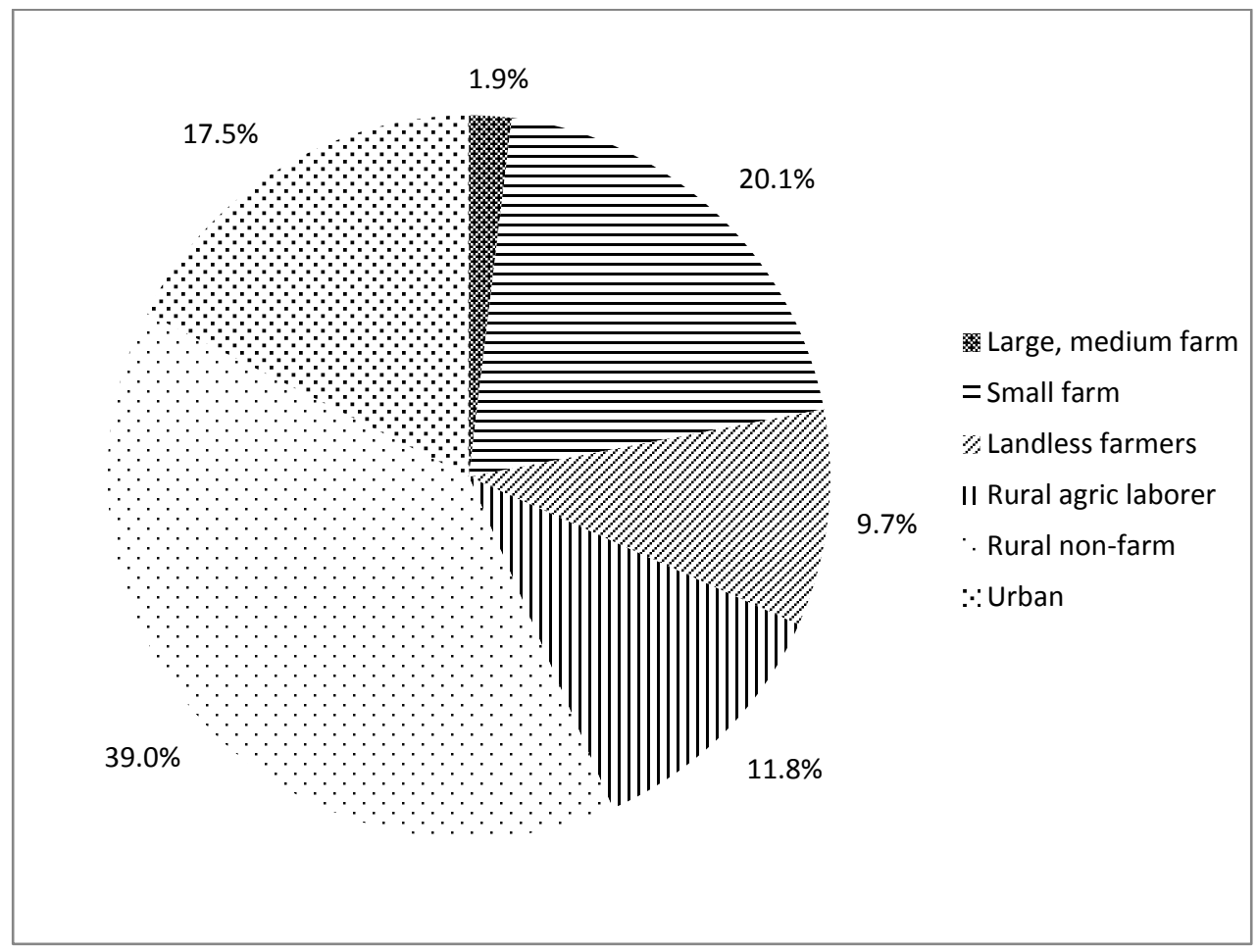

Source: Pakistan HIES 2007-08 


\section{REFERENCES}

Agricultural Prices Commission. 2003. Pakistan Price Statistics 2002-03. Islamabad: Government of Pakistan.

Agricultural Prices Commission. 2009. Pakistan Price Statistics 2008-09. Islamabad: Government of Pakistan.

Debowicz, D. 2010. Modelling trade and financial liberalisation effects for Argentina. University of Sussex: DPhil in Economics.

Dorosh, P., M.K. Niazi, and H. Nazli. 2003. "Distributional Impacts of Agricultural Growth in Pakistan: A Multiplier Analysis." The Pakistan Development Review 42 (3): 249-275.

Dorosh, P., M.K. Niazi, and H. Nazli. 2004. A Social Accounting Matrix for Pakistan, 2001-02: Methodology and Results. Islamabad: Pakistan Institute of Development Economics.

Federal Board of Revenue. Customs Tariff. 2007-08. Accessed February 15, 2012. www.fbr.gov.pk/Docs/20101181511252278TarrifChapter1-972007-2008.pdf www.fbr.gov.pk/Docs/201011815112643390TarrifChapter98-992007-2008.pdf.

Federal Bureau of Statistics. Gross National Product at current factor cost. 2007-08. Accessed February 15, 2012. www.pbs.gov.pk/sites/default/files/national_accounts/tables/table4.pdf

Federal Bureau of Statistics. 1991. Input-Output Matrix 1991. Islamabad: Statistics Division, Government of Pakistan.

Federal Bureau of Statistics. 1993. Social Accounting Matrix for 1984-85. Islamabad: Statistics Division, Government of Pakistan.

Federal Bureau of Statistics. 2001. Survey on Community and Personal Services. Islamabad: Statistics Division, Government of Pakistan.

Federal Bureau of Statistics. 2002. Study on wholesale and retail trade, hotels and restaurants in Pakistan. Islamabad: Statistics Division, Government of Pakistan.

Federal Bureau of Statistics. 2004. National Accounts of Pakistan: Rebasing from 1980-81 to 1999-2000. Islamabad: Statistics Division, Government of Pakistan.

Federal Bureau of Statistics. 2006. Census of Manufacturing Industries 2005-06. Islamabad: Statistics Division, Government of Pakistan.

Federal Bureau of Statistics. 2008. Household Income and Expenditure Survey (HIES) 2007-08. Islamabad: Statistics Division, Government of Pakistan.

Golan, A., G. Judge, and D. Miller. 1996. Maximum Entropy Econometrics: Robust Estimation with Limited Data. New York: John Wiley \& Sons.

Golan, A., G. Judge, and S. Robinson. 1994. "Recovering Information from Incomplete or Partial Multisectoral Economic Data." The Review of Economics and Statistics 76 (3) 541-549.

Haggblade, S., J. Hammer, and P. Hazell. 1991. "Modeling Agricultural Growth Multipliers." American Journal of Agriculture Economics 73 (2) 361-374.

Haggblade, S., P.B.R. Hazell, and T. Reardon. 2007. Transforming the Rural Nonfarm Economy. Baltimore: Johns Hopkins University Press.

International Monetary Fund. 2010. IMF Country Report No. 10/158. Washington, DC: International Monetary Fund.

Judge, G. and R. Mittelhammer. 2012. An Information Theoretic Approach to Econometrics. Cambridge: Cambridge University Press.

Mellor, J. W. 1995. Agriculture on the Road to Industrialization. Baltimore: Johns Hopkins University Press.

Ministry of Finance. 2009. Economic Survey 2008-09. Islamabad: Economic Advisor Wing, Finance Division, Government of Pakistan. 
Ministry of Commerce. Monthly Statements Showing Exports and Imports Of Select Commodities 2010-11 Accessed February 15, 2012. www.commerce.gov.pk/?page_id=7.

Ministry of Food and Agriculture. 2009. Agricultural Statistics of Pakistan 2008-09. Islamabad: Economic Wing, Government of Pakistan.

Pakistan Institute of Development Economics. 2001. Pakistan Rural Household Survey 2001.

Pal, B. D., S. Pohit, and J. Roy. 2012. Social Accounting Matrix for India. Economic Systems Research 24 (1): 77-99.

Pakistan Institute of Development Economics. 1985. A Social Accounting Matrix of Pakistan for 1979-80. Islamabad: Pakistan Institute of Development Economics.

Robinson, S., A. Cattaneo, and M. El-Said. 2001. Updating and Estimating a Social Accounting Matrix Using Cross Entropy Methods. Economic Systems Research 13 (1): 47-64.

Siddiqui, R. and Z. Iqbal. 1999. Social Accounting Matrix of Pakistan for 1989-90. Islamabad: Pakistan Institute of Development Economics

State Bank of Pakistan. 2010. Handbook of Statistics on Pakistan Economy. Government of Pakistan.

UNCTAD Statistics. Accessed March 20, 2012 http://unctad.org/en/Pages/Statistics.aspx.

Waheed, A. and M. Ezaki. 2008. "Aggregated and Compact Disaggregated Financial Social Accounting Matrices for Pakistan." Journal of Economic Cooperation 29 (4): 17-36.

Zellner, A. 2004. Statistics, Econometrics, and Forecasting. Cambridge: Cambridge University Press.

About the Authors

Dario Debowicz is a Post-Doctoral Fellow in the Development Strategy and Governance Division of IFPRI.

Paul Dorosh is the Division Director of the Development Strategy and Governance Division of IFPRI.

Sherman Robinson is a Senior Research Fellow in the Environment and Production Technology Division and Development Strategy and Governance Division of IFPRI.

Syed Hamza Haider is a Senior Research Assistant in the Development Strategy and Governance Division of IFPRI.

\section{INTERNATIONAL FOOD POLICY RESEARCH INSTITUTE}

2033 K Street, NW | Washington, DC 20006-1002 USA | T+1.202.862.5600 | F+1.202.457.4439 | Skype: ifprihomeoffice | ifpri@cgiar.org

\section{PAKISTAN STRATEGY SUPPORT PROGRAM | http://pssp.ifpri.info/}

This Working Paper has been prepared as an output for the Pakistan Strategy Support Program, funded by USAID, and has not been peer reviewed. Any opinions stated herein are those of the author(s) and do not necessarily reflect the policies or opinions of IFPRI.

Copyright $\odot$ 2012, International Food Policy Research Institute. All rights reserved. To obtain permission to republish, contact ifpri-copyright@cgiar.org. 